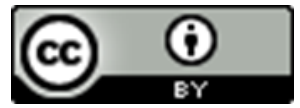

\title{
ENSINO SUPERIOR E TRANSFORMAÇÃO SOCIAL: DECOLONIZAR A UNIVERSIDADE NA PERSPECTIVA DA IGUALDADE RACIAL ${ }^{1}$
}

Hélder Pires Amâncio ${ }^{2}$

Resumo: O ensino superior como prática social e campo de investigação, vem ganhando mais espaço no debate acadêmico nas últimas décadas em todo o mundo. A sua emergência e consolidação resulta do lugar que ocupa nas políticas públicas, nos programas e nas estratégias de desenvolvimento político, econômico, social e cultural a nível global e do seu potencial de transformação social sustentável (construção de mundos e relações sociais mais justas e democráticas). Apesar do reconhecimento e relevância do seu papel para a transformação social, a maioria dos sistemas de ensino superior/ universidades arrasta consigo uma herança colonial e seus paradigmas - a colonialidade do saber, do ser e do poder - contribuindo para a reprodução e reforço da hegemonia eurocêntrica, baseada na heteronormatividade, branquitude e progresso como valores supremos da modernidade.

Palavras-chave: decolonialidade, ensino superior, igualdade racial e transformação social.

\section{HIGHER EDUCATION AND SOCIAL TRANSFORMATION: DECOLONIZE THE UNIVERSITY IN THE PERSPECTIVE OF RACIAL EQUALITY}

Abstract: Higher education as a social practice and research field, has been gaining more space in the academic debate in recent decades around the world. Its emergence and consolidation results from its place in public policies, programs and strategies for political, economic, social and cultural development at global level and its potential for sustainable social transformation (building worlds and more just and democratic social relations). Despite the recognition and relevance of their role for social transformation, most higher education systems / universities carry with them a colonial heritage and its paradigms - the coloniality of knowledge, being and power - contributing to the reproduction and reinforcement of hegemony eurocentric, based on heteronormativity, whiteness and progress as supreme values of modernity.

\footnotetext{
${ }^{1}$ Texto apresentado no Workshop "Educação superior e transformação social: descolonização e igualdade racial" na Universidade de Brasília.

2 Doutorado em Antropologia Social pela Universidade Federal de Santa Catarina (UFSC). E-mail: hpamancio@gmail.com; ORCID: https://orcid.org/0000-0001-6726-2169
} 
Keywords: decoloniality, higher education, racial equality and social transformation.

\section{EDUCACIÓN SUPERIOR Y TRANSFORMACIÓN SOCIAL: DESCOLONIZAR LA UNIVERSIDAD DESDE LA PERSPECTIVA DE LA IGUALDAD RACIAL}

Resumen: La educación superior como campo de investigación y práctica social, ha ido ganando más espacio en el debate académico en las últimas décadas en todo el mundo. Su surgimiento y consolidación resulta de su lugar en las políticas públicas, programas y estrategias de desarrollo político, económico, social y cultural a nivel global y su potencial de transformación social sostenible (construcción de mundos y relaciones sociales más justas y democráticas). A pesar del reconocimiento y la relevancia de su papel para la transformación social, la mayoría de los sistemas de educación superior / universidades llevan consigo una herencia colonial y sus paradigmas - la colonialidad del conocimiento, el ser y el poder - que contribuyen a la reproducción y refuerzo de la hegemonía eurocéntrico, basado en la heteronormatividad, la blancura y el progreso como valores supremos de la modernidad.

Palabras-clave: descolonialidad, educación superior, igualdad racial y transformación social.

\section{ENSEIGNEMENT SUPERIEUR ET TRANSFORMATION SOCIALE: DECOLONISER L'UNIVERSITE SOUS L'ANGLE DE L'EGALITE RACIALE}

Résumé: L'enseignement supérieur en tant que pratique sociale et domaine de recherche a gagné plus de place dans le débat académique au cours des dernières décennies à travers le monde. Son émergence et sa consolidation résultent de sa place dans les politiques publiques, programmes et stratégies de développement politique, économique, social et culturel au niveau mondial et de son potentiel de transformation sociale durable (construire des mondes et des relations sociales plus justes et démocratiques). Malgré la reconnaissance et la pertinence de leur rôle dans la transformation sociale, la plupart des systèmes d'enseignement supérieur / universités portent avec eux un héritage colonial et ses paradigmes - la colonialité du savoir, de l'être et du pouvoir - contribuant à la reproduction et au renforcement de l'hégémonie eurocentrique, basée sur l'hétéronormativité, la blancheur et le progrès comme valeurs suprêmes de la modernité.

Mots-clés: décolonialité, enseignement supérieur, égalité raciale et transformation sociale.

\section{INTRODUÇÃO}

A verdade não cabe numa só boca.

(Proverbio antigo em língua bambara)

In: José Macedo, 2016. 
Hoje é amplamente aceite a ideia de que o ensino superior em sua variedade de formas, contribui para o desenvolvimento social e econômico através de pelo menos quatro grandes missões, a saber: a formação do capital humano (principalmente através do ensino); a construção de bases de conhecimento (principalmente através de pesquisa e desenvolvimento de conhecimento); a disseminação e uso do conhecimento (interagindo com os usuários do conhecimento); a manutenção do conhecimento (armazenamento intergeracional e transmissão de conhecimento) (BITZER e WILKINSON, 2009, p.369).

Várias questões podem ser colocar aqui, relativamente à essa ideia, algumas delas são: Que conhecimento é esse produzido pelo ensino superior/Universidade? A parir de que pressupostos teórico-conceituais e metodológicos ele é produzido? De onde vem tais pressupostos? Quais problemas/ preocupações e a quem esse conhecimento visa responder? Para quê e para quem esse conhecimento é (re)produzido? Que valores e possibilidade de futuros são alimentados ou prejudicados? Estas questões nos colocam diante de dilemas éticos e políticos da atividade universitária a qual não podemos de modo algum escapar ou evitar, pelo contrário, com elas devemos nos defrontar (LANDER, 2000).

O ensino superior é considerado pela literatura da área como um setor universal da sociedade. No entanto, as estruturas, o desenvolvimento, os currículos e propósitos educacionais, a organização e governança do mesmo variam muito e estão profundamente ancoradas a contextos nacionais, culturais e políticos (SCHWARZ \& TEICHLER, 2000; BITZER \& WILKINSON, 2009). Esta afirmação mostra-se ainda mais verdadeira no âmbito das pesquisas empíricas do ensino superior, na medida em que fica evidente a existência de países

[...] onde apenas algumas estatísticas básicas estão disponíveis, onde as visões do ensino superior são gerais e onde a base dos relatórios dos especialistas nem sempre é sólida. Mas existem alguns clubes de país onde as instituições e agências envolvidas no ensino superior têm unidades que são responsáveis pela recolha sistemática de informações e pesquisas sobre o ensino superior, onde a pesquisa sobre o ensino superior é uma característica estável de pesquisa transdisciplinar nas ciências humanas e sociais e onde o ensino estabelecido da educação superior como campo de estudo e pesquisa sobre o ensino superior está entrelaçado de acordo com modos comuns de ligação (TCHWARZ \& TEICHLER, 2000, p.1).

No excerto anterior, sobressaem as desigualdades no processo de produção de conhecimento, especialmente voltado para o ensino superior, mas que se estende também em outras áreas de conhecimento. A pesquisa, especificamente na área do ensino superior, 
está mais desenvolvida no Norte Global que no Sul Global. Isso acontece por razões históricas, econômicas e políticas de reprodução e distribuição de desigualdades no mundo. O Sul Global aqui "identifica-se com uma proposta epistémica e política, alternativa ao projeto colonial capitalista e patriarcal” (MENESES, 2015, p. 45), coincidindo apenas parcialmente com o Sul geográfico. Portanto, deve ser entendido como um projeto político e epistêmico que busca um mundo cada vez democrático e com justiça social em todos os âmbitos, não se tratando de uma entidade monolítica, homogênea e sem conflitos de interesse (BALLESTRIN, 2020), mas heterogêneo e que assume diferentes e complexas configurações dependendo dos contextos sociais.

Apesar da relevância e do reconhecimento do potencial para a transformação e justiça social, a maioria dos sistemas do ensino superior arrastam consigo uma herança colonial e seus paradigmas - colonialidade do saber, do ser e do poder - constitutivas da modernidade (QUIJANO, 2005; MIGNOLO, 2005; 2017; WALSH, OLIVEIRA \& CANDAU, 2018; LANDER, 2005; CASTRO-GÓMEZ, 2005). Nesse contexto, contribuem (consciente ou não) para reprodução e reforço da hegemonia cultural, econômica e política ocidental, baseada na heteronormatividade, na branquitude e no progresso como valores supremos da modernidade (eurocêntrica e colonial).

No presente texto, pretendo refletir sobre as possibilidades de descolonização do ensino superior, especificamente da Universidade na perspectiva da igualdade racial, baseado fundamentalmente na revisão da literatura e observação de algumas experiências de descolonização da Universidade em curso. A discussão em torno deste tema é relevante, sobretudo, no âmbito da formação de professores universitários e da educação básica, onde infelizmente ainda predomina a cultura eurocêntrica e a colocando-se a necessidade de repensar e/ou aperfeiçoar as políticas públicas voltadas para os negros, especialmente no contexto brasileiro.

Analisar tais possibilidades não é uma tarefa fácil e simples, num contexto como este em que nos encontramos, de um mundo em rápidas transformações globais que influenciam as dinâmicas locais na definição de políticas e, por conseguinte, nas concepções e no funcionamento das instituições do ensino superior e das Universidades (públicas ou privadas), que constituem o foco da minha análise neste ensaio. Para o efeito, é preciso visibilizar os mecanismos de reprodução da colonialidade, da desigualdade e do racismo nestas instituições, reflexões que ainda têm pouco lugar dentro das instituições acadêmicas (LOPÉZ, 2012). 
Assim, irei desenvolver os meus argumentos no texto estruturando-os em três partes. A primeira na qual discutirei a relação entre o ensino superior e a transformação social procurando responder à questão: como o ensino superior pode contribuir ou efetivamente contribui para a transformação social? A resposta a esta questão já aparece em parte anunciada no primeiro parágrafo desta introdução. A segunda na qual procuro articular alguns conceitos e sistematizar alguns dos principais debates sobre a (de)colonialidade, sua relação com o ensino superior ou Universidade e a igualdade racial. A terceira parte onde irei avançar algumas pistas ou possibilidades que vislumbro de descolonização da Universidade na perspectiva da igualdade racial, tendo em conta as experiências e exemplos que já estão em curso em algumas das Universidades do Sul Global, no Brasil, na África do Sul e em Moçambique respectivamente. Finalmente, apresentarei breves considerações finais que serão uma espécie de síntese das reflexões desenvolvidas ao longo deste ensaio.

\section{EDUCAÇÃO SUPERIOR E TRANSFORMAÇÃO SOCIAL}

Em teses sobre Feuerbach, Karl Marx afirmou e com razão, que "os filósofos se limitaram a interpretar o mundo de diferentes maneiras, a questão é transformá-lo" (MARX, 1845). A educação enquanto um fenômeno inerente aos seres humanos e, portanto, indispensável à humanidade (MOREIRA, 2011), assume um lugar fundamental no processo de mudança social. À educação, cabe um papel fundamental na construção de ideias de paz, de liberdade, de justiça social, etc. Contudo, a fé no papel essencial da educação como fator de desenvolvimento contínuo das pessoas e sociedades não deve levar a sua concepção como um "remédio milagroso", mas como um caminho que pode possibilitar um desenvolvimento mais harmonioso, mais democrático, mais justo e que seja capaz de fazer recuar a pobreza, as desigualdades e exclusão social, as incompreensões, as opressões, as violências, as guerras, etc. (DELORS, 1998). Assim, podemos visualizar o papel transformador que a educação pode desempenhar nas várias sociedades. Educação aqui entendida no seu sentido lato e não restrito apenas à dimensão escolar.

Baseada na crença do potencial transformador da educação, agora no sentido restrito, de educação escolar e especialmente ao nível superior que, em 1988, a UNESCO lançou uma série de consultas coletivas com as principais ONGs do ensino superior. $\mathrm{O}$ 
principal objetivo dessas consultas era construir uma plataforma de intercâmbio permanente de idéias sobre os problemas enfrentados pelo ensino superior em todo o mundo, bem como, um quadro para a ação conjunta nesse campo. O ensino superior atravessava uma crise (e continua). Assim, a UNESCO pretendia, criar relações de trabalho para a concretização dessa parte importante de sua missão através da promoção da cooperação intelectual internacional e "ajuda" aos Estados membros em seus esforços para desenvolver sistemas e instituições de ensino superior (em países considerados em vias de desenvolvimento) (UNESCO, 1991).

Uma segunda consulta do mesmo tipo foi realizada pela UNESCO em Paris no ano de 1991 e de acordo com o relatório da mesma, confirmou-se plenamente o valor dessas consultas/abordagens. Além das ONGs, outras instituições manifestaram vontade de associar-se ao grupo. Nessa ocasião, organizações intergovernamentais, incluindo o Banco Mundial, a Comunidade Econômica Europeia, também foram convidadas e sua presença introduziu uma nova dimensão no que diz respeito ao leque de questões, discussões abrangidas, incluiu-se a diversidade de abordagens na pesquisa para possíveis soluções aos problemas identificados.

Estas consultas da UNESCO, mostram como o ensino superior é um campo importante e de interesses diversos, como se pode atestar pelas instituições envolvidas. Entretanto, essa importância não é neutra, ela precisa ser questionada: a quem importam essas consultas? A quem efetivamente beneficiam esses estudos? Porque esse investimento em consultas no ensino superior? Essas e outras questões são pertinentes para evidenciar o carácter sócio-histórico, econômico e político do ensino superior e dos estudos a ele relacionados. Apesar dos interesses e das relações desiguais de poder nas condições de estruturação do ensino superior entre os países do Sul e do Norte, isso não deslegitima ou não retira o valor e a importância da educação superior e do trabalho realizado por tais instituições, mas precisamos questionar os interesses e resultados das ações por elas desenvolvidas, pois, apesar do trabalho por elas realizado, as Universidades africanas, por exemplo, nunca saíram da crise e continuam dependentes e reféns intelectual, política e economicamente das instituições: Porquê? Eis a pergunta! A manutenção do poder está certamente no centro do entendimento dessa questão que se manifesta de forma complexa, nos diferentes contextos. 
Darcy Ribeiro argumentou em seu livro “A Universidade Necessária” que, a crise da Universidade a pouco mencionada, tem também carácter intelectual e ideológico, além de conjuntural, político e estrutural. Segundo o autor,

Os primeiros [de carácter intelectual e ideológico], representados pelos desafios de estudar a própria universidade a fim de conhecer, as condições a que está sujeita e os requisitos para sua transformação. Os últimos [de carácter conjuntural, político e estrutural], porque os próprios universitários se dividem em relação ao carácter destas transformações, uma vez que elas tanto podem contribuir para que a universidade opere, ainda mais eficazmente, como agente de conservação da ordem instituída, como para que se constitua em um motor de transformação da sociedade global (RIBEIRO,1969, p.8-9).

Como também demonstrou Paulo Freire, baseado em Simone de Beauvoir, em seu livro Pedagogia do Oprimido - ao argumentar que, "na verdade, o que pretendem os opressores 'é transformar a mentalidade dos oprimidos e não a situação que os oprime', e isto para que, melhor adaptando-os a esta situação, melhor os domine". Fica então evidente que, nem toda a transformação visa uma mudança em relação ao anteriormente estabelecido. As transformações, podem inclusive, operar efeitos contrários aos que supostamente se pretendem, com o objetivo de conservar a situação no lugar de emancipar/libertar as pessoas da opressão.

Quando nos referimos a transformação social neste ensaio, ela significa o segundo movimento apontado por Ribeiro (1969), que contraria a conservação da ordem instituída e avança para a sua desestabilização, instaurando uma nova ordem, mais democrática e socialmente justa. Portanto, trata-se aqui da defesa de um ensino superior ou Universidade que possibilite o acesso aos grupos sociais historicamente excluídos e marginalizados, bem como, de aceitação de outras epistemologias que estes grupos trazem para dentro das Universidades ao acessar o ensino superior. É esta a transformação que a Universidade deve operar. Nesse sentido, o ensino superior ou a Universidade contribuirá para a mobilidade social e econômica desses grupos (ATLBACH, 2014).

Para que a transformação da Universidade/ ensino superior ocorra, não devemos, como sugere Bell Hooks (2019) temer o erro ou o engano, pois, se tivermos medo "nunca transformaremos a academia num lugar culturalmente diverso, onde tanto os acadêmicos quanto aquilo que eles estudam abarque todas as dimensões dessa diferença" (HOOKS, 2019, p.49). Assim, 
Todos nós, na academia e na cultura como um todo, somos chamados a renovar nossa mente [e corações] para transformar as instituições educacionais - e a sociedade - de tal modo que nossa maneira de viver, ensinar e trabalhar possa refletir nossa alegria diante da diversidade cultural, nossa paixão pela justiça e nosso amor pela liberdade (Ibid., p.50).

\section{INTERCULTURALIDADE, DE(S)COLONIALIDADE, ENSINO SUPERIOR E}

\section{IGUALDADE RACIAL}

Catarine Walsh (2005), no seu texto "interculturalidade ${ }^{3}$, conhecimento e decolonialidade", sugeriu uma noção ampliada da interculturalidade, para pensá-la como projeto político e epistemológico, assim como é a categoria do Sul Global. Entender a interculturalidade, nessa perspectiva, permite "ir além da simples relação entre grupos, práticas e pensamentos culturais" e "transbordar a incorporação dos tradicionalmente excluídos dentro das estruturas educativas ${ }^{4}$, disciplinares e de pensamento existentes, assim como, sua redução à criação de programas 'especiais' de educação 'normal' e “universal” (não bilíngue)" (WALHS, 2005, p.39). Para Walsh, trata-se de "enfrentar, transformar e tornar visíveis as estruturas e instituições que diferencialmente posicionam grupos, práticas e pensamentos dentro de uma ordem que, ao mesmo tempo e, todavia, é, racial, moderna e colonial" (Ibid.).

Esta perspectiva apresentada por Walsh (2005), em meu entender, é passível de uma articulação com a proposta do filósofo moçambicano José Castiano (2010, p.217), que em sua reflexão sobre "o diálogo entre culturas através da educação" sugere uma acepção igualmente política e epistemológica da interculturalidade, baseada em FornetBettancourt, vista enquanto atitude, experiência ou vivência - a disposição do ser humano em se capacitar para habituar-se a viver suas referências culturais/identitárias com os “outros", não podendo o termo ser confundido com o de multiculturalismo como por vezes se adota (FORNET-BETTANCOURT, 2004).

A reflexão à volta da interculturalidade, tanto de Walsh (2005), como de Castiano (2010), permite-nos perceber que as Universidades ou Instituições do Ensino Superior

\footnotetext{
${ }^{3}$ Walsh (2005) argumenta que este conceito na América Latina tem sua maior referência no campo educativo, especialmente na educação bilíngue e indígena, porém, nos últimos anos o mesmo se estendeu para outros campos, como o da filosofia. "Não obstante e apesar de vinte anos de uso, a interculturalidade continua sendo um termo pouco explorado e entendido, as vezes significa nada mais que a simples relação entre culturas" (WALSH, 2005, p.40).
}

${ }^{4}$ No caso que nos interessa aqui das Instituições do Ensino Superior/Universitárias Públicas. 
(educacionais no geral), funcionam mais numa lógica da multiculturalista do que da interculturalidade e, desse modo, invisibilizam, na sua organização e modo de funcionamento, a colonialidade do saber, do ser, do poder (QUIJANO, 2005; MIGNOLO, 2005; WALSH, 2005) e de gênero (LUGONES, 2008). É por esta razão, que os conceitos de interculturalidade, (de)colonialidade e igualdade racial são pertinentes e convocados a esta conversa. Eles permitem visibilizar as estruturas coloniais que sustentam a maioria das Instituições de Educação Superior/ Universidades e contra as quais devemos lutar para transformá-las.

Antes de me aprofundar no debate sobre a decolonialidade e igualdade racial, preciso fazer um recuo para falar, primeiro, da "colonialidade". Este um conceito introduzido pelo sociólogo e pensador humanista peruano Aníbal Quijano nos finais da década de 1980 e início de 1990 do século passado e elaborado posteriormente por Walter Mignolo em seu livro Histórias locais/ projetos globais e em outros trabalhos (MIGNOLO, 2017) .

A colonialidade "[...] é um conceito que dá conta de um dos elementos fundantes do atual padrão de poder, a classificação social básica e universal da população do planeta em torno da idéia de "raça"' (QUIJANO, 2002, p. 4). Esta ideia, bem como, a classificação social e racial que está na sua base, originadas há mais de 500 anos com a América, a Europa e o capitalismo:

São a mais profunda e perdurável expressão da dominação colonial e foram impostas sobre toda a população do planeta no curso da expansão do colonialismo europeu. Desde então, no atual padrão mundial de poder, impregnam todas e cada uma das áreas de existência social e constituem a mais profunda e eficaz forma de dominação social, material e intersubjetiva, e são, por isso mesmo, a base intersubjetiva mais universal de dominação política dentro do atual padrão de poder (Ibid.).

Quijano (2002) argumentou que as pesquisas sobre os processos de globalização e suas relações com as tendências atuais das formas institucionais de dominação, especialmente do Estado-Nação, não se podem furtar de encarar a questão do poder: "toda discussão dessas questões implica de todo modo uma perspectiva teórica e histórica sobre a questão do poder[...]” (QUIJANO, 2002, p. 4). Nessa abordagem, segundo ele, o poder é caracterizado como um tipo de relação social constituído pela presença simultânea e permanente de três elementos: dominação, exploração e conflito. Desse modo o atual padrão de poder mundial constitui-se na articulação entre: 
1) a colonialidade do poder; isto é, a idéia de "raça" como fundamento do padrão universal de classificação social básica e de dominação social; 2) o capitalismo, como padrão universal de exploração social; 3) o Estado como forma central universal de controle da autoridade coletiva e o moderno Estado-nação como sua variante hegemônica; 4) o eurocentrismo como forma hegemônica de controle da subjetividade/ intersubjetividade, em particular no modo de produzir conhecimento" (Ibid., grifos meus).

\section{Carlos Walter Porto Gonçalves \& Pedro de Araújo Quental (2012) baseados em}

Quijano argumentam que, em sentido amplo, os processos de classificação social estão intrinsecamente relacionados com a questão do poder na sociedade, na medida em que, "se referem aos lugares e às posições que indivíduos e grupos sociais ocupam (ou devem ocupar) no controle das dimensões básicas da existência social". Para estes autores, com os quais estou de pleno acordo:

As classificações sociais não são atributos naturais ou biológicos já dados pela realidade, mas construções históricas que, erguidas nas relações sociais, naturalizam-se no próprio processo de reprodução e manutenção de um determinado padrão de poder. Não determinam os indivíduos e grupos sociais, mas os fazem, na mesma medida em que também por eles são refeitas (Quijano, 2000). Considerando essa acepção mais abrangente, é que, em uma dimensão mais restrita, o autor [Quijano, 2000] irá compreender a noção de classificação racial da população mundial. A partir, então, da conquista da América, [...] trabalho, raça e gênero se articulam como os três eixos principais de classificação social do novo padrão mundial de poder. As diferenças fenotípicas, como por exemplo, a cor da pele, a forma e cor do cabelo, dos olhos, do nariz, começam a ser utilizadas no processo de colonização como forma de diferenciar conquistadores e conquistados, europeus e não-europeus, estabelecendo, assim, uma relação de superioridade e inferioridade pautada nas distintas estruturas biológicas de cada grupo social e criando supostas gradações de seres humanos. Assim, são criadas identidades sociais até então não existentes, como índio, negro e mestiço. Designações que, como sabemos, homogeneizaram em um único termo, uma imensa diversidade de povos, como é o caso das culturas Inca, Maia, Asteca, Zapoteca, Guarani, Quéchua, Aimara, Banto entre tantas outras que tiveram suas diferenças reduzidas a uma única categoria social (Porto-Gonçalves, 2003). É com a invenção eurocêntrica da América, portanto, que surge o conceito de raça; maneira de legitimar as relações de dominação impostas pela conquista e estabelecer o controle europeu sobre todas as formas de subjetividade, cultura, e produção do conhecimento (Quijano, 2005). Nenhum dos habitantes do continente que conhecemos como África jamais se chamou de negro, assim como os europeus até então jamais haviam se chamado de branco. A distinção/discriminação das pessoas com a noção pseudo-científica de raça é parte de um sistema de poder mundial que nos habita até hoje. Assim, embora a raça não exista como conceito científico, o racismo existe como fenômeno social real. Os negros e os povos originários que o digam e, costumam dizer com a força de um conhecimento que não é só conhecimento, mas conhecimento com 
sentimento na medida em que o racismo não é simplesmente uma idéia, mas prática cotidianamente sofrida (GONÇALVES \& QUENTAL, 2012, p. 6).

Neste excerto, vislumbra-se a pertinência dos conceitos de decolonialidade, interculturalidade e igualdade racial aqui convocado. Estes entendidos, não só como conceito, mas articulados com um projeto político e epistemológico outro.

O conceito de igualdade racial, emerge como resultado da discriminação e da desigualdade racial, ou seja, do racismo como bem exposto acima, entendido, por um lado, como "um comportamento, uma ação resultante da aversão, por vezes, do ódio, em relação a pessoas que possuem um pertencimento racial observável por meio de sinais, tais como: cor da pele, tipo de cabelo, etc." E, por outro lado, como "um conjunto de idéias e imagens referente aos grupos humanos que acreditam na existência de raças superiores e inferiores. O racismo também resulta da vontade de se impor uma verdade ou uma crença particular como única e verdadeira" (GOMES,2005, p.52).

O silenciamento sobre a questão racial faz com que, cada vez mais, a existência do racismo, da discriminação e da desigualdade racial, seja mais reforçada. Este é, infelizmente, o modo particular da manifestação do racismo no Brasil, por exemplo, onde "ele se afirma através da sua própria negação" (GOMES, 2005, p.46). Por isso mesmo, a Nilma Gomes e outros autores como Kabengele Munanga, afirmam que no Brasil vivese "um racismo ambíguo" ou "velado", que:

[...] se apresenta, muito diferente de outros contextos onde esse fenômeno também acontece. O racismo no Brasil é alicerçado em uma constante contradição. A sociedade brasileira sempre negou insistentemente a existência do racismo e do preconceito racial, mas, no entanto, as pesquisas atestam que, no cotidiano, nas relações de gênero, no mercado de trabalho, na educação básica e na universidade os negros ainda são discriminados e vivem uma situação de profunda desigualdade racial quando comparados com outros segmentos étnicoraciais do país (GOMES, 2005, p.46).

No Brasil, apesar da Constituição Federal de 1988, que reconhece de forma inédita a presença do racismo e do preconceito racial, bem como, a necessidade de combatê-los e promover a igualdade racial, assim também, a valorização dos diferentes grupos que compõem a sociedade brasileira (JACCOUD at al., 2009, p.361), o racismo persiste. O racismo no Brasil é estrutural, na medida em que, não se pode examinar e compreender a sociedade contemporânea brasileira sem considerar os conceitos de raça e racismo, porque estes "integram a organização econômica e política da sociedade" (ALMEIDA, 
2018, p.15). O Brasil é "um país com uma estrutura racista onde a cor da pele de uma pessoa infelizmente é mais determinante para o seu destino social do que o seu caráter, a sua história, a sua trajetória" (GOMES, 2005, p.46). O racismo "é a manifestação normal" da sociedade brasileira (ALMEIDA, 2018).

O racismo é também institucional, na medida em que, “[...] atua de forma difusa no funcionamento cotidiano de instituições e organizações, provocando uma desigualdade [violenta] na distribuição de serviços, benefícios e oportunidades aos diferentes segmentos da população do ponto de vista racial”' (LÓPEZ, 2012, p. 121). Essa desigualdade racial na distribuição de serviços, benefícios e oportunidades é muitas vezes naturalizada e invisibilizada pelos mecanismos de funcionamento das instituições, incluindo as do Ensino Superior/ Universidades que são o foco de nossa reflexão no presente texto. Para perceber essa desigualdade, basta um exercício simples, olhar para a "paisagem socioracial" que compõe as Universidades brasileiras - negros e indígenas são muito poucos nos cursos de graduação e pós-graduação, como professores, muito menos ainda, apesar de serem a maioria da população e as políticas do governo Lula e Dilma terem feito muito pela promoção de direitos sociais.

Não por acaso, Walter Mignolo (2017) define a colonialidade como "o lado mais escuro da modernidade", ou seja, o lado invisibilizado/ silenciado. Assim a colonialidade é porque, "[...] nomeia a lógica subjacente da fundação e do desdobramento da civilização ocidental desde o Renascimento até hoje, da qual colonialismos históricos tem sido uma dimensão constituinte, embora minimizada" (MIGNOLO, 2017, p.2). Embora Mignolo, use colonialidade como um conceito central das suas reflexões e produções teóricas, argumenta e concordo com esse ponto de vista, que:

O conceito [...] não pretende ser [...] totalitário, mas um conceito que especifica um projeto particular: o da ideia da modernidade e do seu lado constitutivo e mais escuro, a colonialidade, que surgiu com a história das invasões europeias de Abya Yala, Tawantinsuyu e Anahuac, com a formação das Américas e do Caribe e o tráfico maciço de africanos escravizados. A "colonialidade" já é um conceito "descolonial", e projetos descoloniais podem ser traçados do século XVI ao século XVIII. E, por último, a "colonialidade" (por exemplo, el patrón colonial de poder, a matriz colonial de poder - MCP) é assumidamente a resposta específica à globalização e ao pensamento linear global, que surgiram dentro das histórias e sensibilidades da América do Sul e do Caribe. É um projeto que não pretende se tornar único. Assim, é uma opção particular entre as [...] opções descoloniais (Ibid.). 
Essa matriz colonial/ padrão mundial de poder, que inferioriza, classifica, hierarquiza, racializa, descrimina está, como apontamos acima, subjacente na estrutura da maioria das Instituições de Ensino Superior/ Universidade. Portanto, estes que são considerados espaços por excelência de produção do conhecimento (científico), historicamente arrastam consigo a colonialidade, uma vez inseridas em sociedade marcadas por ela.

O conhecimento, como sabemos está estreitamente relacionado com a geografia, com a política e com a cultura, consolidada em uma mesma ordem do mundo e no mapa que o representa, aquele que orienta nossa perspectiva desde a nossa entrada na escola (WALSH 2005, p.41). Isso significa, que o mesmo, não pode ser pensado fora da geopolítica na qual é produzido. A questão que se coloca, então, é: qual é a representação que o mapa-múndi constrói sobre a geografia, a política, a cultura, o poder e o saber a ela associado, sobre o norte e sul, sobre as regiões economicamente poderosas em relação as outras, especialmente as hoje designadas em desenvolvimento e outrora de Terceiro Mundo? Eduardo Galeano avançou uma resposta a esta pergunta ao argumentar que:

Aprendemos a geografia do mundo em um mapa que não nos mostra o mundo tal e qual é, mas tal e qual os seus desenhadores mandam que seja. No planisfério tradicional, que se usa nas escolas e em todas as partes, o equador não está no centro, o Norte ocupa dois terços e o Sul, um. A América Latina abarca no mapamúndi menos espaço que a Europa e muito menos que os Estados Unidos e Canadá, quando na realidade a América Latina é duas vezes mais grande que a Europa e bastante maior que os Estados Unidos e o Canadá. O mapa, que nos encolhe, simboliza todo o resto. Geografia roubada, economia sequestrada, história falsificada, usurpação cotidiana da realidade do chamado Terceiro Mundo, habitado por gente de terceira, cobre menos, come menos, recorda menos, vive menos, diz menos (GALEANO, s.d apud WALSH, 2005, p.41).

Aqui emerge outro conceito importante o de "colonialidade do saber". Como argumentou Castro-Gómez (2000, p.93) "a colonialidade do poder e a colonialidade do saber se encontram colocadas numa mesma matriz genética". O que isto quer dizer? Que ambas estão dentro do que os autores do campo de(s)colonial chamam de uma "matriz colonial". A colonialidade do saber está bem exemplifica no trecho de Eduardo Galeano, na medida em que, na representação geopolítica dominante, única, globalizada e universal do mundo, não cabem outras possibilidades como, por exemplo, o mapa virado cabeçaabaixo do povo indígena de Abya Yala, no qual o Sul (América Latina e África) aprece em cima e o Norte (Estados Unidos, Canadá e Europa) em baixo, e o Sul mais grande que 
que o Norte sugerindo uma outra lógica de pensamento, outra geopolítica ou conceptualização do mundo, radicalmente diferente (WALSH, 2005). Como argumentou Edgardo Lander, a colonialidade do saber, está associada ao carácter,

[...] não só eurocêntrico, mas articulado a formas de domínio colonial e neocolonial dos saberes das ciências sociais e humanidades, não tem que ver apenas com o passado, com as "heranças coloniais" das ciências sociais, mas joga igualmente um papel medular no domínio imperial/neocolonial do presente (LANDER, 2000, p.26).

Essa lógica de pensamento é governada pela primazia total do mercado, cuja defesa mais coerente foi formulada pelo neoliberalismo, do qual fazem parte a ordem política, econômica, social e também do conhecimento (LANDER, 2000; WALSH, 2005). Desse ponto de vista, o conhecimento é parte constitutiva da construção e organização do sistema-mundo moderno que, ao mesmo tempo é colonial. Em outras palavras, isso significa dizer, que "a história do conhecimento está marcada geohistoricamente, geopoliticamente e geoculturalmente e tem um valor, cor e lugar de origem" (WALSH, 2005, p.41). Um exemplo desta afirmação, segundo Walsh, pode ser observado no pensamento do reconhecido filósofo Immanuel Kant que teria argumentado nos séculos XVIII e XIX que a única raça capaz de evoluir no âmbito educacional/ do conhecimento das ciências e das artes é a branca europeia (Ibid.).

Infelizmente e, com tristeza essa concepção permanece encrustada nas mentes das pessoas e estruturas das instituições de ensino (universitárias) ainda que de forma silenciosa, mas com efeitos extremamente violentos. Em pleno século XXI, há ainda pessoas e instituições que pensam que os negros e indígenas, bem como, outros grupos historicamente excluídos são incapazes de pensar por si próprios e de gerir sua vida ou de ter autonomia. As mesmas, defendem que a Universidade/ o ensino superior é apenas para alguns seguimentos, fundamentalmente brancos e com condições socioeconômicas, não para os pobres, negros e indígenas. Até no acesso ao conhecimento, persiste ainda a segregação, se estabelece um quadro hierárquico para acessá-lo ou não, há lugar e há raça. A ideia de um conhecimento neutro não passa de uma ilusão da modernidade que esconde a colonialidade do poder, do ser e do saber.

Do meu ponto de vista, isso não significa, que os filósofos e pensadores modernos devam ser descartados, mas que a leitura deles deve ser sempre cuidadosa e crítica de modo a não reproduzirmos ideias preconceituosas presentes nos escritos dos seus tempos. 
É da leitura crítica teórica aos antigos filósofos e pensadores, mas também, prática dos colonialistas que nasceu a decolonialidade.

O conceito de decolonialidade é aqui entendido no sentido originalmente desenvolvido pelo filósofo porto-riquenho Nelson Maldonado-Torres, de "giro decolonial". CastroGómez \& Grosfoguel (2007) sugere que este conceito seja complementar à categoria de descolonização, na medida em que a sua relevância, resultada da potencial utilidade que o mesmo possui para "transcender as suposições de certos discursos acadêmicos e políticos, segundo os quais, com o fim das administrações coloniais e a formação dos Estados-nação nas periferias, vivemos agora em um mundo descolonizado e póscolonial" (CASTRO-GÓMEZ \& GROSFOGUEL, 2007, p.13).

Antes pelo contrário, o pressuposto das análises decoloniais é de que, mesmo com o fim do colonialismo e formação dos novos Estados nacionais no Sul Global, não houve uma transformação significativa no âmbito da divisão internacional de trabalho entre os centros e periferias, nem das hierarquias étnico-raciais das populações que se formaram durante os longos séculos de expansão colonial europeia. O que assistimos, foi

Uma transição do colonialismo moderno à colonialidade global, processo que certamente transformou as formas de dominação exibidas pela modernidade, mas não a estrutura das relações centro-periferia em escala mundial. As novas instituições do capital global, como o Fundo Monetário Internacional (FMI) e o Banco Mundial (BM), bem como organizações militares como a OTAN, as agências de inteligência e o Pentágono, todas formadas após a Segunda Guerra Mundial e o suposto fim do colonialismo, mantem a periferia em posição subordinada (CASTRO-GÓMEZ \& GROSFOGUEL, 2007, p.13).

São estas e muitas outras instituições que ditam as políticas de desenvolvimento em muitos países considerados em vias de desenvolvimento e influenciam agendas e políticas de funcionamento e de pesquisa das instituições do ensino superior. $\mathrm{O}$ capitalismo global contemporâneo "resignifica, em um formato pós-moderno, as exclusões provocadas pelas hierarquias epistêmicas, espirituais, raciais/ étnicas e de gênero/sexualidade implantadas pela modernidade" (CASTRO-GÓMEZ \& GROSFOGUEL, 2007, p.14), observamos isso nas instituições de educação superior, por isso, a relevância de um enfoque decolonial, do qual me aproprio.

DECOLONIZAR A UNIVERSIDADE NA PERSPECTIVA DA IGUALDADE RACIAL: ALGUMAS POSSIBILIDADES DE (RE) EXISTÊNCIAS 
Não há dúvidas de que "as Universidades dos países marcados por histórias coloniais e imperiais possuem um grande desafio (MAYORGA, 2016, p.1). No caso brasileiro, Darcy Ribeiro, foi um dos que alertou para isso e visualizou alguns dos desafios. Segundo ele, a maior responsabilidade da Universidade é a capacidade de exercer as suas funções de "órgão de criatividade cultura e científica", bem como, de "conscientização e crítica da sociedade". Ao mesmo tempo, ele reconheceu que, "satisfazer aos requisitos indispensáveis ao bom desempenho destas funções é tarefa muito difícil para qualquer Universidade, particularmente para as Universidades das nações subdesenvolvidas, onde isto é mais necessário" (RIBEIRO, 1991, p.241).

A Universidade, como observou Ribeiro (1969, p.216), foi em sua origem e continua sendo em muitos lugares do mundo, um espaço privilegiado de acesso ao poder de algumas pessoas apenas. Ela se constituiu historicamente como uma instituição destinada a formação da classe dirigente e dos filhos da classe dominante e, assim funciona, como sistema de seleção de indivíduos pela classe, raça e gênero. Mayorga (2016, p.1) retoma e atualiza este argumento ao defender que as Universidades "foram constituídas sob os princípios e interesses das elites locais a partir de fundamentos marcadamente eurocêntricos, isto é, princípios que tomaram as sociedades europeias e mais tarde, norte-americanas, como referências culturais e sociais".

Ainda sobre este aspecto, uma das referências importantes no campo dos estudos do ensino superior, Philip Altbach, também reconhece o carácter elitista da Universidade ao argumentar que o modelo universitário universalmente usado no mundo de hoje surgiu na Europa do século XI, com o estabelecimento das Universidades de Bolonha e Paris e mais tarde em outras partes da Europa (ALTBACH, 2014, p.11). Na sua argumentação, Altbach (2014), mostra que a Universidade moderna é uma invenção [localizada] para atender a poucos (a elite), que veio a dominar o mundo. Essa invenção globalizou-se e hoje, ela é uma grande empresa em todo o mundo. O autor argumenta ainda que, a sua massificação aumentou drasticamente as matrículas globais e este crescimento e expansão, a par do surgimento da chamada "economia global de conhecimento" transformaram as instituições do ensino superior colocando ênfase nas "Universidades de pesquisa", que se situam hoje no topo do ensino acadêmico. Essas transformações 
implicaram na conservação e reprodução também das hierarquias e do que poderíamos chamar de "racismo científico global"s.

$\mathrm{O}$ argumento do eurocentrismo constitutivo da Universidade, foi igualmente defendido pelo sociólogo venezuelano Edgardo Lander, que nas suas investigações sobre os vínculos entre a Universidade latino-Americana e a colonialidade do saber, argumentou que as ciências sociais e humanidades ${ }^{6}$ ensinadas na maior parte das Universidades, não só arrastam consigo a "herança colonial" e seus paradigmas, mas, pior do que isso, contribuem para reforçar a hegemonia cultural, econômica e política ocidental (CASTRO-GÓMEZ, 2007, p.79). De acordo com Edgardo Lander:

A formação profissional [oferecida pela universidade], a pesquisa, os textos que circulam, as revistas que são recebidas, os locais onde são realizados os cursos de pós-graduação, os regimes de avaliação e o reconhecimento de seu corpo docente, todos apontam para a reprodução sistemática de uma visão do mundo [...] a partir das perspectivas hegemônicas do Norte, o que Fernando Coronil chamou de globocentrismo (LANDER, 2000, p.43).

Nesta parte do ensaio, pretendemos apresentar algumas possibilidades de decolonização da Universidade na perspectiva da igualdade racial. As propostas/possibilidades que iremos apresentar aqui não são novas, já foram colocadas por outros/as autores/as e, parte delas estão em prática em algumas das Universidades do Sul global, mas precisamos, porém, insistir na importância desse movimento para forçar as tendências conservadoras da ordem instituída a ceder espaço às transformações que visem a democratização do espaço universitário, do processo de produção do conhecimento (CONNELL, 2012) e reconhecimento da localização limitada do conhecimento e do conhecimento localizado (HARAWAY, 1995), bem como, estender essas iniciativas para um número maior de Universidades.

Para o efeito, a Universidade deve fazer em primeiro lugar um movimento de conhecer-se a si mesma para se transformar (HOUNTONDJI, 2008; RIBEIRO, 1969). Ou seja, é preciso que a Universidade/ ensino superior, não só invista na pesquisa fora dela (da Universidade), como é fundamental que o faça sobre e dentro dela própria, com vista a orientar políticas de ensino superior e tomada de decisão (RUMBLEY et al. 2014),

\footnotetext{
${ }^{5}$ Que consiste na crença pseudocientífica de que o conhecimento científico ocidental é superior à todos os outros tipos de conhecimento. Esta crença é global porque se difundiu para todo o mundo como verdade indiscutível e, portanto, universal e imutável.

${ }^{6}$ Este argumento pode ser estendido a demais áreas do conhecimento científico.
} 
com vista à democratização e justiça social ${ }^{7}$. O ensino superior não deve ser apenas lugar de produção e transmissão de conhecimento, mas também, ele próprio e os conhecimentos produzidos, bem como, os modos de os transmitir (ensinar e aprender), devem ser transformados em objetos de investigação e reflexão crítica constante.

Antes de avançar para outras possibilidades de descolonização da Universidade a primeira questão a enfrentar é, o que isso significa. Para responder a esta questão baseamo-nos em Castro-Gómez (2007), para quem em primeiro lugar, significa ou passa por identificar os legados coloniais do conhecimento que são sistematicamente reproduzidos pela Universidade, ou seja, pela investigação dos mesmos. Esse legado tem como base o modelo epistemológico moderno, denominado por Castro-Gómez como "os hybris $^{8}$ do ponto zero", que dependendo contexto pode se apresentar de maneiras distintas. Santiago Castro-Gómez defende que "a Universidade reproduz este modelo, tanto no tipo de pensamento disciplinar que incorpora, como na organização arbórea de sua estrutura" (CASTRO-GÓMEZ, 2007, p.79).

Nesse sentido, a Universidade, se inscreve na chamada estrutura triangular da colonialidade: do ser, do saber e do poder (CASTRO-GÓMEZ, 2007, p.79-80), mas também do gênero (LUGONES, 2008). Se os modos de colonialidade podem se manifestar de formas distintas, a descolonização também pode ser vista/ concebida de formas igualmente distintas: por um lado como coisa do passado, por outro como imperativo de ação política no presente (MALDONALDO-TORRES, 2013, p.11).

Apesar do cenário tendencialmente negativo, Castro-Gómez (2007) sugere, que dentro da Universidade se estão a incorporar (ou nos termos da Walsh (2005) se estão a transbordar) novos paradigmas de pensamento e organização que poderão ajudar a quebrar as armadilhas do triângulo moderno/ colonial anteriormente mencionado, ainda que este processo seja muito precário (CASTRO-GÓMEZ, 2007, p.80).

\footnotetext{
${ }^{7}$ É importante lembrar que o campo dos estudos do ensino superior é mais ou menos recente. O mesmo surge nos meados do século XX, como fruto da sua expansão a nível global. Nesse contexto, ficou evidente que o conhecimento do empreendimento acadêmico era necessário e que a administração ou gestão das instituições e dos sistemas do ensino superior exigiam conhecimento para o efeito (ALTBACH, 2014).

${ }^{8}$ Em grego esse termo se refere ao descaso ou desprezo que se tem pelo outro. Na perspectiva do autor essa noção se refere ao grande pecado do ocidente de pretender trazer um ponto de vista único sobre todos os outros pontos de vista e, sem que sobre este ponto de vista do ocidente se possa igualmente ter um ponto de vista. Portanto é a defesa e legitimação de uma visão única e universal do mundo (CASTRO-GÓMEZ, 2007).
} 
Existe ao nosso ver vários níveis nos quais a decolonização da Universidade pode ser operada. Em síntese identificamos três, inter-relacionados entre si e, portanto, inseparáveis: o macro, o mêso e o micro. O primeiro nível é referente a toda a estrutura de funcionamento da Universidade que impacta nos níveis subsequentes. O segundo nível é das diferentes instâncias que compõem a Universidade (faculdades e centros/ Departamentos/ programas) e o terceiro é referente às práticas cotidianas de ensino e aprendizagem/pedagógicas em sala de aula ${ }^{9}$.

Indo direto ao ponto, uma das possibilidades de descolonização da Universidade visualizada por Castro-Gómez (2007) e outros/as autores/as que gostaríamos de retomar, é a emergência da transdisciplinaridade e do pensamento complexo dentro da Universidades a partir da/o qual, ele sugere que poderíamos começar a estabelecer pontes para fazermos o que ele denomina por diálogo transcultural de saberes que se aproxima bastante do conceito de interculturalidade proposto por Walsh (2005) e Castiano (2010). Este diálogo consistiria em colocar em perspectiva o paradigma da complexidade e promover a transdisciplinaridade no lugar da disciplinaridade e da interdisciplinaridade. Mas, por que não promover essas duas últimas? Porque a primeira tende a produzir o conhecimento compartimentado e fragmentado e, a segunda apesar de promover o contato entre as diferentes áreas disciplinares mantém intactos os fundamentos filosóficos de cada área evitando a confrontação crítica (CASTIANO, 2010).

A transculturalidade na perspectiva de Castro-Gómez (2007) (e interculturalidade na perspectiva de Walsh, 2005 e Castiano, 2005) permitiria ir além, e efectivamente mexer nesses fundamentos ao trazer a ideia de que uma coisa pode ser igual ao seu contrário dependendo do nível de complexidade tido em conta. A lei de coincidencia oppositorium negligenciada pelo pensamento analítico disciplinar e interdisciplinar é introduzida pela transdisciplinaridade para a qual o conhecimento e a vida, por exemplo, seriam contrários inseparáveis. Em vez de separar, "a transculturalidade nos permite ligar (link) os diversos elementos e formas de conhecimento, [...] incluindo os que a modernidade havia considerado como tóxicos" (CASTRO-GÓMEZ, 2007, p.87). Este é um exemplo de uma decolonização que pode ser operada a nível macro da Universidade e que tem ou pode e deve ter efeitos nos restantes níveis aos quais nos referimos.

\footnotetext{
${ }^{9}$ Sala de aula por nós concebida vai para além das quatro paredes físicas. Referimo-nos aqui a qualquer espaço onde a aprendizagem possa ocorrer dentro ou fora da Universidade, mas a ela relacionada.
} 
A ideia acima colocada, permite pensar a Universidade como uma instituição rizomática e não arborificado. Apropriámo-nos aqui da noção proposta por Deleuze \& Guattari (1997), entendida não só como um conceito, mas como um método de trabalho que guarda paralelos com a noção de rede. "Num rizoma entra-se por qualquer lado, cada ponto se conecta com qualquer outro, não há um centro, nem uma unidade presumida em suma, o rizoma é uma multiplicidade[...]” (PELBART, 1997, s.p.).

Uma boa analogia pode ser feita com as raízes de uma planta que se espalham horizontalmente e não nos permitem distinguir a origem de cada uma delas, no entanto, as mesmas se conectam), no lugar de arbórea (como uma árvore que cresce verticalmente, fixa e cujas ramificações conhecemos as origens e não se encontram ao longo do seu crescimento/florescimento). Assim, nessa lógica (rizomática), diferentes formas de produção de conhecimento podem conviver sem cada uma delas estar submetida a uma lógica única e hegemônica.

Castro-Gómez (2007) argumenta, nessa perspectiva, que uma Universidade que pensa complexamente, assim também deve funcionar. A questão é como proceder para que assim a universidade funcione? É difícil dar uma resposta acabada a esta pergunta, pensando que o exercício mesmo de colocar em prática qualquer proposta de decolonização da Universidade deve ser vigilante e reflexivo para evitar reproduzir o que se pretende combater, pois, a colonialidade opera com mecanismos bastante sutis e de difícil percepção. Por outro lado, a ideia deste ensaio é propor maneiras de (re)pensar as práticas universitárias e não modelos prontos e universais. Propor um modelo, iria inclusivamente contra a intenção deste ensaio, no qual pensamos que em cada contexto, as condições de operar mudanças não podem ser as mesmas, ou melhor, cada contexto vai exigir estratégias diferentes de operar tais mudanças que devem ser equacionadas ou inventadas de acordo com os mesmos (HOOKS, 2019).

Ao nível micro ou do cotidiano da Universidade, há muito também que se pode fazer para decolonizar as práticas pedagógicas que refletem o modelo da Universidade colonial que nos é imposto. Assim como as mudanças do nível macro ou mêso podem ter efeitos transformativos ao nível micro, a mesma assertiva funciona no caso contrário. $\mathrm{O}$ livro da Bell Hooks (2019), Ensinando a transgredir: a educação como prática da liberdade e o editado por Catherine Walsh (2013), Pedagogías decoloniales: prácticas insurgentes de resistir, (re)existir y (re) vivir apontam para essa direção. Tanto Bell Hooks quanto Catherine Walsh, demonstram como as salas de aulas/academias e as práticas 
pedagógicas podem contribuir para a liberdade e autonomia dos sujeitos e, desse modo, ser anticoloniais/anti-opressivas, possibilitando "os processos e práticas de (re)humanização frente à estruturas materiais e simbólicas que assediam a humanidade dos seres humanos" (MALDONADO-TORRES, 2013, p.11).

Se para Walsh (2013) descolonizar a pedagogia passa pelo processo/ prática de desaprender o imposto e reaprender outras formas possíveis de aprender e ensinar, para Hooks $\left(2019\right.$, p.15) a decolonização ${ }^{10}$ da educação no âmbito mais amplo, passa por imaginar "modos pelos quais o ensino e a experiência do aprendizado poderiam ser diferentes" do imposto, pela crítica ao que Paulo Freire (1987) chamou de uma "concepção bancária da educação" apropriada por Hooks chamando-a de um "sistema de educação bancária" produtora de tédio, distante da realidade dos sujeitos aprendizes e reprodutora da dominação. Nas reflexões das duas autoras, observamos que a ideia de uma ação política para a liberdade é o fio condutor que anima todo o pensamento delas em torno da questão.

Como argumentou Maldonado-Torres (2013, p.11) a pedagogia é via de regra vista simplesmente como um veículo através do qual vários conteúdos são ensinados, não muito mais do que isso. É uma área considerada importante, mas nunca da mesma maneira que o que se ensina (conteúdo). Assim, a pedagogia como veículo deve sempre estar subordinada ao seu conteúdo. Isto significa, segundo o autor, que um especialista em certo tipo de conteúdo, presta pouca atenção às formas como o mesmo é ensinado ou à pedagogia. Entretanto, se considerarmos a pedagogia como parte indispensável da colonialidade, ela não pode ser negligenciada, na medida em que, ela não é apenas um discurso sobre como ensinar ou um meio para o efeito, ela é também um modo de fazer, de dizer, é portanto, uma prática que, como bem apontou o filósofo caribenho e afroamericano Lewis Gordon (2010) é (a pedagogia) parte constitutiva do que ele chamou de "boa-fé crítica"11 que consiste na necessidade de estar continuamente atento ou vigilante em relação ao que se considera evidência e bons critérios de julgamento sobre algo

\footnotetext{
${ }^{10}$ Embora a autora use o conceito de educação como prática da liberdade/ libertação, o sentido é o mesmo que atribuímos o conceito de descolonização aqui, não só como coisa do passado, mas sobretudo, como ação política.

${ }^{11}$ Segundo o autor a boa-fé não é o contrário da má-fé, na medida em que esta última é a nossa tentativa de nos escondermos da responsabilidade que temos como produtores e descobridores do conhecimento (GORDON, 2010). A reflexão sistematicamente crítica aparece nos trabalhos de todas/os as/os autoras/es decoloniais aos quais tivemos acesso como motor da transformação social para um mundo de inclusão, mais justo e democrático.
} 
(conhecimento), pois, "para ensinar, alguém deve aprender, mas não apenas aprender.

Deve-se também aprender a aprender" (GORDON, 2010, p.31).

Gordon (2010) vai mais longe ao falar de "imperativos pedagógicos" que são igualmente constitutivos do processo de emergência de sujeitos e comunidades cuja existência e história é negada pelas instituições várias, incluindo as do ensino superior como o excerto a seguir aponta: "a existência da universalidade é defendida pela negação de seu limite; isto é, uma rejeição do 'exterior', negando a sua existência” (Ibid.).

As Universidades baseadas no modelo colonial negam a existência da descriminação racial/étnica e das desigualdades econômicas, sociais e de gênero. Elas negam em geral, todas as identidades sociais e políticas dos sujeitos colocados à margem das sociedades em que vivem. Tudo isso, para dizer que, a descolonização da Universidade e o processo de sua "humanização frente a colonialidade e neoliberalismo racial e desumanizador global, envolve imperativos pedagógicos" (MALDONADOTORRES, 2013, p.12).

Por isso, Walsh (2013, p.15) enfatiza a ideia de que temos que "reaprender sobre relações humanas", "aprender entre pares" como parte de um compromisso que assumimos, com as experiências baseadas na conversação, no fazer coletivo para além dos muros da Universidade/ das instituições de ensino em geral. Bell Hooks (2019) defende essa mesma ideia de trabalho coletivo/ comunitário, de fazer junto quando argumenta, por exemplo, que o entusiasmo ${ }^{12}$ pela ideia de aprender não é suficiente para criar um processo de aprendizado empolgante na sala de aula, pois a sua criação não é individual, pelo contrário, constitui-se num esforço coletivo. Assim,

Na comunidade de sala de aula, nossa capacidade de gerar entusiasmo é profundamente afetada pelo nosso interesse uns pelos outros, por ouvir a voz dos outros, por reconhecer a presença uns dos outros. [...] A visão constante de ver a sala de aula como um espaço comunitário aumenta a possibilidade de haver um esforço coletivo para criar e manter uma comunidade de aprendizado (HOOKS, 2019, p.17-18).

\footnotetext{
${ }^{12}$ Segundo Hooks (2019) "o entusiasmo no ensino superior era visto [e continua] como algo que poderia perturbar a atmosfera de seriedade considerada essencial para o processo de aprendizado. " Por essa razão a autora defende que "entrar numa sala de aula de faculdade munida da vontade de partilhar o desejo de estimular o entusiasmo era [e ainda é ] um ato de transgressão", na medida em que, gerar entusiasmo significa "reconhecer plenamente que as práticas didáticas não podem ser regidas por um esquema fixo e absoluto". Pelo contrário, os esquemas devem ser flexíveis e "levar em conta possibilidade de mudanças espontâneas de direção" (HOOKS, 2019, p.17).
} 
De acordo com Hooks (2019), uma aula empolgante ou aprendizagem entusiasmante, pode coexistir com uma atividade intelectual ou acadêmica séria e até promover tal seriedade. Ou seja, o afeto e a razão não são aspectos nitidamente separadas e mutuamente excludentes, mas imbricados. Como nos sugere Castro-Gómez (2007), ambos são aparentemente contraditórios inseparáveis. Ao apontar para aspectos aparentemente desprezíveis como a atenção com/para o outro/ conhecer o outro, o afeto, o compromisso com o que se faz e a construção coletiva do conhecimento e das práticas de ensino e aprendizagem no ensino superior, Hooks (2019) sugere-nos ferramentas importantes para a decolonização da Universidade no cotidiano.

Assim, a presença dos corpos de pessoas negros/as e indígenas que entram para a Universidade e o reconhecimento dos mesmos como "corpos que sabem"13 para usar a expressão de Cecília McCallum (1998), carregados/as de histórias e epistemologias outras que não cabem na epistemologia ocidental e, por esta última invisibilizadas, silenciadas e encobertas (BULHÕES, 2018), que tencionam pela sua presença, a abertura de espaço à diversidade de pensamento corporificado e que resistem ao modelo cartesiano de organização das salas de aula e do conhecimento é uma ação aparentemente simples, mas difícil, portanto, que necessita de persistência e reflexividade sistemática sobre nossas concepções e práticas.

Como referimos alguns parágrafos atrás, há iniciativas sendo gestadas e levadas a cabo, dignas de menção como ações políticas decoloniais do ensino superior/ Universidades. No caso do Brasil, por exemplo, a criação de instituições Universitárias concebidas com um viés de inclusão, como é o caso da UNILAB ${ }^{14}$ e da UNILA ${ }^{15}$. A introdução de uma Licenciatura Intercultural Indígena na UFSC ${ }^{16}$ (MELO, 2014), das Políticas de Ação afirmativa e de Cotas (GOMES, 2005; GOMES \& RODRIGUES, 2018; SANTOS; 2013; JACCOUD, 2009) e de educação diferenciada (TASSINARI \& COHN, 2012; JESUS, 2012; ALBUQUERQUE \& NAKASHIMA, 2012) são ações políticas que,

\footnotetext{
${ }^{13}$ Cecília McCallum (1998, p.227) elabora essa noção baseada na etnografia entre os Kaxinawá e na ideia de que "o corpo precisa aprender para agir socialmente". Assim, a ação social pública do corpo é uma "exteriorização do conhecimento" que pode tomar diversas formas - ação física, fala ou canto, por exemplo.

${ }^{14}$ Universidade da Integração Internacional da Lusofonia Afro-Brasileira.

${ }^{15}$ Universidade Federal da Integração Latino-Americana.

${ }^{16}$ Universidade Federal de Santa Catarina.
} 
possuem em sua base, uma visão decolonial, ainda que os efeitos nem sempre sejam os esperados.

A entrada de populações negras e indígenas, entre outros segmentos historicamente excluídos do ensino superior, tem obrigado as Universidades a (re)pensarem-se e (re)criarem-se, ainda que num processo bastante lento e, às vezes, intercalado o avanço, com retrocessos imensos, como os que assistimos com a ascendência de governos de direita no Brasil e não só. Este sujeitos e intelectuais negros e indígenas, vem produzindo trabalhos na Universidade que questionam grandes obras clássicas e tradições de conhecimento cristalizadas ao longo da história, abrindo espaço para novas teorizações, invenções metodológicas e categorias analíticas, algumas vezes negligenciadas porque entendidas como sendo menos importantes pelos anteriores pesquisadores ou simplesmente não vistas por aqueles sendo "investigadores de fora". A perspectiva de "dentro" e baseada na experiência própria dos negros e indígenas vem cada vez mais se mostrando relevante e indispensável no campo da produção de conhecimento, permitindo uma articulação necessária e equilibrada deste último com o saber ${ }^{17}$ e abertura de novas linhas de pesquisa.

No caso sul-africano e Moçambicano, podemos citar como exemplos, o ensino e “padronização" das línguas locais ${ }^{18}$ nas Universidades Públicas (WITS ${ }^{19}, \mathrm{UEM}^{20}$; UP ${ }^{21}$ ) como ações decoloniais, na medida em que, há algum tempo atrás, elas eram proibidas e consideradas "não-línguas" e, entendidas como incapazes de produzir e transmitir conhecimentos científicos aos olhos coloniais. Não obstante o trabalho árduo, perseverante e rico que se tem feito no campo da Linguística e outras áreas de conhecimento, o uso destas línguas nas e pelas instituições do Estado e privadas, especialmente no processo de ensino e aprendizagem, assim como da pesquisa, ainda constitui um grande desafio nesses países e também no Brasil o desafio se coloca. Por que as centenas de línguas indígenas não são ou são pouco ensinadas nesses país? Por que

\footnotetext{
${ }^{17}$ Para uma distinção entre conhecimento e saber, ver Ingold (2019); Hill Collins (2019) e Carvalho (2019).

${ }^{18}$ No caso de Moçambique o Português é a única língua oficial, já no caso sul-africano, as línguas oficiais são onze: IsiNdebele, Sepedi, SeShotho sa Borwa, SiSwati, XiTsonga, SeTswana, TshiVenda, IsiXhosa, IsiZulu, Afrikaans e o Inglês.

${ }^{19}$ University of Witwatersrand, South Africa.

${ }^{20}$ Universidade Eduardo Mondlane.

${ }^{21}$ Universidade Pedagógica, Moçambique.
} 
o inglês e francês são obrigatórias para cursar o mestrado e doutorado e não é conhecer pelo menos uma língua indígena do próprio país? Estas são questões que precisam ser encaradas com seriedade!

Iniciativas como o "Encontro de Saberes", "uma proposta de inclusão de mestres e mestras dos saberes tradicionais na docência Universitária brasileira, implementada em nove Universidades brasileiras e também na Colômbia" (CARVALHO, 2019, p. 83), são exemplos, de ações e possibilidades de descolonização da Universidade/ do ensino superior.

A decolonização, além de alguns dos elementos já apontados, passa também pela criação de infraestruturas ou arquiteturas materiais, pois, "a vida intelectual pode depender [e depende] do tipo de edifícios em que as conversas acontecem" (MBEMBE, 2016, p.30). Para demonstrar esse argumento, Mbembe exemplifica com recurso à arquitetura do apartheid que ainda prevalece na maioria das instituições de ensino superior sul-africanas, que não é propícia à respiração. A decolonização, passa também, por quebrar o ciclo, que segundo o autor, tende a transformar as/os alunas/os em clientes e consumidores, nesse contexto, as instituições do ensino superior são vistas como empresas:

Essas tendências são inerentes a uma instituição de acordo com os princípios de negócios: os estudantes se interessam cada vez menos em estudo e conhecimento por si mesmos e cada vez mais no retorno material, ou utilidade, que seus estudos e graduação têm sobre o mercado aberto. Nesse sistema, o aluno se torna o consumidor de mercadorias educacionais vendíveis, principalmente cursos, créditos, certificações e diplomas. A tarefa da universidade, a partir de então, é torná-los felizes como clientes (MBEMBE, 2016, p.31).

\section{CONSIDERAÇÕES FINAIS}

No presente ensaio propusemo-nos a analisar o que significa descolonizar a Universidade na perspectiva da igualdade racial. Ao chegarmos ao fim desta reflexão, se nos pedissem para responder em poucas palavras a essa questão, resumiríamos da seguinte maneira: a decolonização da Universidade na perspectiva da igualdade racial significa imaginar formas de incluir os/as sujeitos/as que historicamente estiveram à margem das sociedades nacionais (que se construíram após o colonialismo) e das instituições educacionais, neste caso particular do ensino superior/ Universidades. Incluir aqui, significa não só a chegada e entrada desses sujeitos/as nessas instituições, mas seu reconhecimento como sujeitos carregados de histórias e conhecimentos tão importantes e 
válidos quanto o ocidental, não sendo, portanto, este último, único e universal, pelo contrário, embora torne isso invisível ele é como todos outros um conhecimento localizado e parcial.

Procuramos ao longo deste ensaio apresentar alguns exemplos ou iniciativas nesse sentido. Fizemos essa tentativa organizando o texto em três eixos, a saber: no primeiro discutindo a relação entre educação superior e transformação social; no segundo refletindo sobre os principais conceitos do trabalho - (de)colonialidade, interculturalidade, igualdade racial e sua relação com o ensino superior; no terceiro e último eixo retomamos o problema da colonialidade e apresentamos brevemente algumas possibilidades e iniciativas (ainda que de forma pontual) de decolonização da Universidade/ ensino superior na perspectiva da igualdade racial, fazendo recurso a exemplos que já estão em prática em Universidades do Sul-global, concretamente no Brasil, na África do Sul e em Moçambique.

Iniciativas como as Políticas de Ações afirmativas e de Cotas, fazem parte do grande guarda-chuva que são as Políticas de Promoção da Igualdade Racial no caso do Brasil (mas também, no caso sul-africano) - introduzidas no governo Lula; a criação de Universidades como a UNILAB e a UNILA que nascem deste movimento de descolonização e promoção da diversidade de pensamento e social; a criação de Licenciaturas Interculturais Indígenas nas Universidades Públicas, o exemplo da UFSC; iniciativas de ensino e estudos das línguas "nativas/locais" em Universidades Públicas moçambicanas e sul-africanos e mesmo o ensino de outras áreas nessas línguas e defesa de teses no caso sul-africano e brasileiro (embora ainda sejam casos isolados); a possibilidade de os alunos fazerem os seus próprios currículos nas Universidades através do curso de disciplinas denominadas em diferentes áreas de conhecimento sem se limitar à sua especialidade é outra iniciativa que, embora ainda tímida e, muito restrita ao campo das ciências sociais, constituem sinais de avanço na direção da decolonização da Universidade. O projeto "Encontro de Saberes" que visa reconhecer e valorizar os sábios e intelectuais indígenas e estabelecer diálogos equilibrados entre o conhecimento e o saber é outra importante e interessante iniciativa no sentido da descolonização.

Para terminar este ensaio com esperança, cito uma passagem do livro de Bell Hooks, curiosamente, o último parágrafo do seu texto. Bell Hooks escreve: 
A academia não é o paraíso. Mas o aprendizado é um lugar onde o paraíso pode ser criado. A sala de aula [em outros termos a Universidade], com todas as suas limitações, continua sendo um ambiente de possibilidades de trabalhar pela liberdade, de exigir de nós e dos nossos camaradas uma abertura da mente e do coração que nos permita encarar a realidade ao mesmo tempo em que, coletivamente, imaginamos esquemas para cruzar fronteiras, para transgredir. Isso é a educação como prática da liberdade (HOOKS, 2019, p.273).

Apesar dela ser estadunidense, é uma intelectual feminista e ativista negra insurgente, influenciada por um pensador brasileiro - Paulo Freire - que luta contra os sistemas de opressão, é a favor e defende a educação como uma prática libertadora. Bell Hooks (2019) alimenta em nós a esperança de que um mundo diferente, um ensino diferente, uma vida diferente, no sentido de mais junta e democrática é possível e, chamanos a atenção para a necessidade de valorizarmos os nossos intelectuais e, mesmo aqueles que estão aliados às nossas concepções e lutas, ainda que não os reconheçamos como nossos!

\section{REFERÊNCIAS BIBLIOGRÁFICAS}

ALBUQUERQUE, Marcos; NAKASHIMA, Edson. Consenso e dissenso: os Pankararu e a educação intercultural na cidade de São Paulo. In: TASSINARI, Antonella; GRANDO, Beleni; ALBUQUERQUE, Marcos (Org.). Educação indígena: reflexões sobre noções nativas de infância, aprendizagem e escolarização. Florianópolis: Ed. da UFSC, 2012.

ALMEIDA, Silvio. Introdução. O que é o racismo estrutural? Belo Horizonte: Letramento, 2018, p.13-16.

ALTBACH, Philip. Knowledge for the Contemporary University: Higher Education as a Field of Study and Training. In: RUMBLEY, Laura at al. (Ed.). Higher Education: A Worldwide Inventory of Research Centers, Academic Programs, and Journals and Publications. Center for International Higher Education, Boston College, 2014.

BALLESTRIN, Luciana. O Sul Global como projeto político. Horizontes ao Sul, 2020. Disponível em: https://www.horizontesaosul.com/single-post/2020/06/30/ O-SUL-GLOBALCOMO-PROJETO-POLITICO

BITZER, Eli \& WILKINSON, Annette. Higher education as a field of study and research. In: Higher Education in South Africa. Stellenbosch: SUN PRESS, 2009, p.369- 408.

BULHÕES, Leandro. Ensino das histórias e culturas africanas, afro-brasileiras e indígenas entrecruzadas: paradigma da contribuição, pedagogia do evento e emancipações na educação básica. In: Revista da ABPN, v. 10, Ed. Especial- Caderno Temático: História e Cultura Africana e Afro-brasileira - lei 10.639/03 na escola, p.22-38, maio de 2018.

CARVALHO, José Jorge. Encontro de Saberes e descolonização: para uma refundação étnica, racial e epistêmica das universidades brasileiras. In: BERNARDINO-COSTA, Joaze; MALDONADO-TORRES; Nelson \& GROSFOGUEL, Ramón. (Org.). Decolonialidade e 
pensamento afrodiaspórico. $2^{\mathrm{a}}$ edição, Belo Horizonte: Autêntica Editora (Coleção Cultura Negra e Identidades), 2019, p.79- 106.

CASTIANO, José P. O diálogo entre as culturas através da educação. CASTIANO, José P.; NGOENHA, Severino. Pensamento engajado: ensaios sobre filosofia africana, educação e cultura política. Maputo: Educar-Universidade Pedagógica, 2010, p.213-249.

CASTRO-GÓMEZ, Ciências sociais, violência epistêmica e o problema da 'invenção do outro'. In: LANDER, Edgardo. (Org.). A colonialidade do saber: eurocentrismo e ciências sociais. Perspectivas latino-americanas. Buenos Aires: CLACSO, Consejo Latinoamericano de Ciencias Sociales, $2005 . \quad$ Disponível em: https://edisciplinas.usp.br/pluginfile.php/2591382/mod_resource/content/1/colonialidade_do_sa ber_eurocentrismo_ciencias_sociais.pdf

CASTRO-GÓMEZ, Santiago \& GROSFOGUEL, Ramón. El giro decolonial: reflexiones para una diversidad epistémica más allá del capitalismo global. Bogotá: Siglo del Hombre Editores; Universidad Central, Instituto de Estudios Sociales Contemporáneos y Pontificia Universidad Javeriana, Instituto Pensar, 2007.

CASTRO-GÓMEZ, Santiago. Ciencias sociales, violencia epistémica y el problema de la invención del otro. In: LANDER, Edgardo (Org.). La colonialidad del saber: eurocentrismo y ciencias sociales. Buenos Aires: CLACSO, 2000, p. 88- 98.

CONNELL, Raewyn. A iminente revolução na teoria social. In: Revista Brasileira de Ciências Sociais, Vol. 27, N 80, 2012.

DELEUZE, Gilles e GUATARI, Félix. Mil Platôs: Capitalismo e Esquizofrenia. (Tradução Suely Rolnik) São Paulo: Ed. 34, 1997

FORNET-BETANCOURT, Raúl. A interculturalidade como alternativa à violência. Razão e Fé, Pelotas, 6(1-2):6 5-16,jan.-dez./2004

FREIRE, Paulo. Pedagogia do Oprimido. 17ª . ed. Rio de Janeiro, Paz e Terra, 1987.

GOMES, Nilma Lino. Alguns termos e conceitos presentes no debate sobre relações raciais no Brasil: uma breve discussão. História. Coleção para Todos. Secretaria da Educação Continuada, Alfabetização e Diversidade - Brasília: Ministério da Educação, 2005.

GOMES, Nilma; RODRIGUES, Tatiane. Resistência democrática: a questão racial e a constituição do federal de 1988. In: Educ. Soc., Campinas, v. 39, nº. 145, out.-dez., 2018, p.928945 .

GONÇALVES, Carlos Walter Porto \& QUENTAL, Pedro de Araújo. Colonialidade do poder e os desafios da integração regional na América Latina. In: Polis-Revista Latinoamericana, 31, 2012.

GORDON, Lewis. A Pedagogical Imperative of Pedagogical Imperatives. In: Thresholds in Education (Spring 2010): 27-35. Disponível em: https://pt.scribd.com/document/133752489/APedagogical-Imperative-of-Pedagogical-Imperatives-Lewis-Gordon

GROSFOGUEL, Ramón. Por uma visão decolonial da crise civilizatória e dos paradigmas da esquerda ocidentalizada. In: COSTA-BERNARDINO, Joaze; MALDONADO-TORRES, Nelson; GROSFOGUEL, Ramón (Org.) Decolonialidade e pensamento afrodiaspórico. 2 ed. Belo Horizonte: Autêntica Editora (Coleção cultura negra e identidade), 2019, p.55-78. 
HARAWAY, Donna. Saberes localizados: a questão da ciência para o feminismo e o privilégio da perspectiva parcial. In: Cadernos Pagu, (5), 1995, p.7-41. Disponível em: https://periodicos.sbu.unicamp.br/ojs/index.php/cadpagu/article/view/1773

HILL COLLINS, Patrícia. Epistemologia feminista negra. In: BERNARDINO-COSTA, Joaze; MALDONADO-TORRES; Nelson \& GROSFOGUEL, Ramón. (Org.). Decolonialidade e pensamento afrodiaspórico. $2^{\mathrm{a}}$ edição, Belo Horizonte: Autêntica Editora (Coleção Cultura Negra e Identidades), 2019, p.139-170.

HOOKS, Bell. Ensinando a transgredir: a educação como prática da liberdade. São Paulo: WMF Martins Fontes, 2019.

HOUNTONDJI, Paulin. Conhecimento de África, conhecimento de Africanos: Duas perspectivas sobre os Estudos Africanos. In: Revista Crítica de Ciências Sociais, 80, 2008, p.149-160. Disponível em: https://filosofiaafricana.weebly.com/uploads/1/3/2/1/13213792/paulin_hountondji_-

conhecimentos de \% C3\%81frica conhecimento de africanos. duas perspectivas sobre os estudos_africanos.pdf

INGOLD, Tim. Antropologia: para que serve? Rio de Janeiro: Vozes, 2019.

JACCOUD, Luciana (Org.). A construção de uma política de promoção da igualdade racial : uma análise dos últimos 20 anos. Brasília: Ipea, 2009.

JACCOUD, Luciana at al. Entre o racismo e a desigualdade: da constituição à promoção de uma política de igualdade racial (1988-2008). In: Políticas Sociais - acompanhamento e análise. Instituto de Pesquisa Econômica Aplicada (Ipea), $\mathrm{n}^{\circ} 17$, vol.3, 2009. Disponível em: http://www.ebooksbrasil.org/adobeebook/feuerbach.pdf

JESUS, Suzana. Acampamentos indígenas no Sul do Brasil: os diversos olhares para a educação e infância Mbyá-Guarani. In: TASSINARI, Antonella; GRANDO, Beleni; ALBUQUERQUE, Marcos (Org.). Educação indígena: reflexões sobre noções nativas de infância, aprendizagem e escolarização. Florianópolis: Ed. da UFSC, 2012.

LANDER, Edgardo (Org.). La colonialidad del saber: eurocentrismo y ciencias sociales. Buenos Aires: CLACSO, 2000.

LANDER, Edgardo. ¿Conocimiento para qué? ¿Conocimiento para quién? Reflexiones sobre la universidad y la geopolítica de los saberes hegemónicos. Estudios Latinoamericanos, nueva época, años VI y VII, N¹2-13, 1999/2000, p.25-46. Disponível em: http://www.revistas.unam.mx/index.php/rel/article/view/52369/46620

LANDER, Edgardo. Ciências sociais: saberes coloniais e eurocentrismo. LANDER, Edgardo. (Org.). A colonialidade do saber: eurocentrismo e ciências sociais. Perspectivas latinoamericanas. Buenos Aires: CLACSO, Consejo Latinoamericano de Ciencias Sociales, 2005. Disponível

em: https://edisciplinas.usp.br/pluginfile.php/2591382/mod_resource/content/1/colonialidade_do_sa ber_eurocentrismo_ciencias_sociais.pdf

LÓPÉZ, Laura Cecília. O conceito de racismo institucional: aplicações no campo da saúde. Interface: Comunicação, Saúde, Educação, v.16, n.40, jan./mar. 2012, p.121-34. 
LUGONES, María. Colonialidad y género. In: Tabula Rasa. Bogotá. Colombia, No.9, , juliodiciembre, 2008, p.73-101.

MACEDO, José. Introdução. O pensamento africano no século XX. São Paulo: Outras expressões, 2016.

MALDONALDO-TORRES, Nelson. A modo de comentario inicial. In: WALSH, Catherine, Pedagogías decoloniales: prácticas insurgentes de resistir, (re)existir y (re) vivir. Tomo I - Serie de Pensamiento decolonial: Ediciones: Abya-Yala, 2013.

MARX, Karl. Teses sobre Feuerbach, 1845. Disponível em: https://www.marxists.org/portugues/marx/1845/tesfeuer.htM

MBEMBE, Achille. Decolonizing the university: New directions. In: Arts \& Humanities in Higher Education, Vol. 15(1), 2016, p. 29-45.

MCCALLUM, Cecília. O corpo que sabe: da epistemologia kaxinawá para uma antropologia médica das terras baixas sul-americanas. In: ALVES, Paulo César; RABELO, Miriam Cristina. (Orgs). Antropologia da saúde: traçando identidade e explorando fronteiras. Rio de Janeiro: Editora FIOCRUZ; Rio de Janeiro: Editora Relume Dumará, 1998. Disponível em: http://books.scielo.org/id/by55h/pdf/alves-9788575414040-12.pdf

MELO, Clarissa Rocha de. Da Universidade à casa de rezas guarani e vice-versa: Reflexões sobre a presença indígena no Ensino Superior a partir da experiência Guarani na Licenciatura Intercultural Indígena do Sul da Mata Atlântica. Florianópolis: UFSC (Tese de Doutorado), 2014.

MENESES, Maria Paula. Os sentidos da descolonização: uma análise a partir de Moçambique. In: Catalão, v. 16, n. 1, jan./jun. 2016, p. 26-44. Disponível em: https://www.revistas.ufg.br/Opsis/article/view/36904

MIGNOLO, Walter. A colonialidade de cabo a rabo: o hemisfério ocidental no horizonte conceitual da modernidade. In: LANDER, Edgardo. (Org.). A colonialidade do saber: eurocentrismo e ciências sociais. Perspectivas latino-americanas. Buenos Aires: CLACSO, Consejo Latinoamericano de Ciencias Sociales, 2005. Disponível em: https://edisciplinas.usp.br/pluginfile.php/2591382/mod_resource/content/1/colonialidade_do_sa ber_eurocentrismo_ciencias_sociais.pdf

MIGNOLO, Walter. Colonialidade o lado mais escuro da modernidade. In: Revista Brasileira de Ciências Sociais - Vol. $32 \quad \mathrm{~N}^{\circ}$ 94, 2017 Disponível em: http://www.scielo.br/scielo.php?pid=S0102-69092017000200507\&script=sci_abstract\&tlng=pt

MOREIRA, Adriano. Educação escolar e transformação social. In: Revista faac, Bauru, Vol.1, $\mathrm{N}^{\circ} .1,2011$, p. 47-57.

PALBERT, Peter Pál. Das abas do livro. In: DELEUZE, Gilles e GUATARI, Félix. Mil Platôs: Capitalismo e Esquizofrenia. (Tradução Suely Rolnik) São Paulo: Ed. 34, 1997

QUIJANO, Aníbal. Colonialidade do poder, eurocentrismo e América Latina. In: LANDER, Edgardo. (Org.). A colonialidade do saber: eurocentrismo e ciências sociais. Perspectivas latinoamericanas. Buenos Aires: CLACSO, Consejo Latinoamericano de Ciencias Sociales, 2005. Disponível em: https://edisciplinas.usp.br/pluginfile.php/2591382/mod resource/content/1/colonialidade do sa ber_eurocentrismo_ciencias_sociais.pdf 
QUIJANO, Aníbal. Colonialidade, poder, globalização e democracia. In: Novos Rumos, ano 17, $\mathrm{N}^{\circ} 37,2002$.

RIBEIRO, Darcy. A Universidade Necessária. Rio de Janeiro: Paz \& Terra, 1969.

RIBEIRO, Darcy. A Universidade Necessária. Rio de Janeiro: Paz \& Terra, 1991.

RUMBLEY, Laura at al. (Ed.). Introduction. In: Higher Education: A Worldwide Inventory of Research Centers, Academic Programs, and Journals and Publications. Center for International Higher Education, Boston College, 2014.

SANTOS, Jocélio Teles dos (Org.). O impacto das cotas nas universidades brasileiras (20042012). Salvador: CEAO, 2013.

SCHWARZ, Stefanie \& TEICHLER, Ulrich (eds). Introduction. In: The institutional basis of higher education research. Dordrecht: Kluwer Academic, 2000, p. 1-10.

TASSINARI, Antonella; COHN, Clarice. Escolarização indígna entre os Karipuna $e$ Mebengokré-Xikrin: uma abertura ao outro. In: TASSINARI, Antonella; GRANDO, Beleni; ALBUQUERQUE, Marcos (Org.). Educação indígena: reflexões sobre noções nativas de infância, aprendizagem e escolarização. Florianópolis: Ed. da UFSC, 2012

WALSH, Catherine, OLIVEIRA, Luiz Fernandes de. \& CANDAU, Vera Maria. Colonialidade e pedagogia decolonial: para pensar uma educação outra. In: Arquivos Analíticos de Políticas educativas, 26(83), 2018. Disponível em: https://epaa.asu.edu/ojs/article/view/3874

WALSH, Catherine. (Ed.). Pedagogías decoloniales prácticas insurgentes de resistir, (re)existir $y$ (re)vivir. Tomo I - Serie Pensamiento decolonial, Abya-Yala, 2013.

WALSH, Catherine. Interculturalidad, conocimientos e decolonialidad. In: Perspectivas y divergencias - signo y pensamiento, Vol. XXIV (46), 2005.

Recebido em: 08/03/2020

Aprovado em 30/09/2020 